\title{
Expression-analysis of the human endogenous retrovirus HERV-K in human astrocytic tumors
}

\author{
Almuth Friederike Kessler ${ }^{1}$, Miriam Wiesner ${ }^{1}$, Joachim Denner ${ }^{2}$, Ulrike Kämmerer ${ }^{3}$, Giles Hamilton Vince ${ }^{1,4}$, \\ Thomas Linsenmann ${ }^{1}$, Mario Löhr ${ }^{1}$, Ralf-Ingo Ernestus ${ }^{1}$ and Carsten Hagemann ${ }^{1 *}$
}

\begin{abstract}
Background: The human endogenous retrovirus K (HERV-K) has been acquired by the genome of human ancestors million years ago. It is the most complete of the HERVs with transcriptionally active gag, pol and env genes. Splice variants of env, which are rec, $1.5 \mathrm{~kb}$ transcript and Np9 have been suggested to be tumorigenic. Transcripts of HERV-K have been detected in a multitude of human cancers. However, no such reports are available concerning glioblastomas (GBM), the most common malignant brain tumor in adults. Patients have a limited prognosis of 14.6 months in median, despite standard treatment. Therefore, we elucidated whether HERV-K transcripts could be detected in these tumors and serve as new molecular target for treatment.

Findings: We analyzed human GBM cell lines, tissue samples from patients and primary cell cultures of different passages for HERV-K full length mRNA and env, rec and $1.5 \mathrm{~kb}$ transcripts. While the GBM cell lines U138, U251, U343 and GaMG displayed weak and U87 strong expression of the full length HERV-K, the splice products could not be detected, despite a weak expression of env mRNA in U87 cells. Very few tissue samples from patients showed weak expression of env mRNA, but none of the rec or $1.5 \mathrm{~kb}$ transcripts. Primary cells expressed the $1.5 \mathrm{~kb}$ transcript weakly in early passages, but lost HERV-K expression with extended culture time.
\end{abstract}

Conclusions: These data suggest that HERV-K splice products do not play a role in human malignant gliomas and therefore, are not suitable as targets for new therapy regimen.

Keywords: Human endogenous retrovirus, HERV-K, Glioblastoma multiforme, Astrocytic tumor, Expression, Glioblastoma cell line, PCR analysis

\section{Findings \\ Background}

Human endogenous retroviruses (HERVs) have been integrated into the genome of human ancestors millions of years ago after ancient germline infections and passed on to the following generations. Today these HERVs comprise about $8 \%$ of the human genome [1]. More than 22 HERV families have been identified [2]. They are classified according to the tRNA primer-binding site which is, for example, in the HERV-K family the lysine (K) tRNA [3,4]. Most of the HERV sequences are silenced due to mutations, deletions or other genetic changes. However, HERV$\mathrm{K}$ is transcriptionally active and able to encode all elements necessary for a functional retrovirus [5-8]. Nevertheless, to

\footnotetext{
*Correspondence: hagemann_c@ukw.de

${ }^{1}$ Tumorbiology Laboratory, Department of Neurosurgery, University of Würzburg, Josef-Schneider-Str. 11, Würzburg D-97080, Germany Full list of author information is available at the end of the article
}

date no infectious HERV-K has been described $[9,10]$. The HERV-K genome consists of three genes for functional and structural proteins which are flanked at the $5^{\prime}$ and the $3^{\prime}$ ends by two long terminal repeat (LTR) sequences (Figure 1). The LTR regions contain regulatory elements like enhancer, promoters, polyadenylation signals and recognition sites for regulatory proteins [11]. The three main genes of HERVs are gag, env and pol. Gag encodes structural genes for the formation of the viral matrix like the capsid structure. The two enzymes reverse transcriptase and integrase are encoded by the gene pol. The former is necessary for the reverse transcription of the viral RNA sequence into DNA and the latter for the integration of this DNA into the genome of the cell. Finally, env encodes for envelope proteins involved in receptor recognition and membrane fusion, as well as the accessory protein Rec $[3,5,12]$. The latter is a regulatory factor localized in the nucleus of cells. It has been 


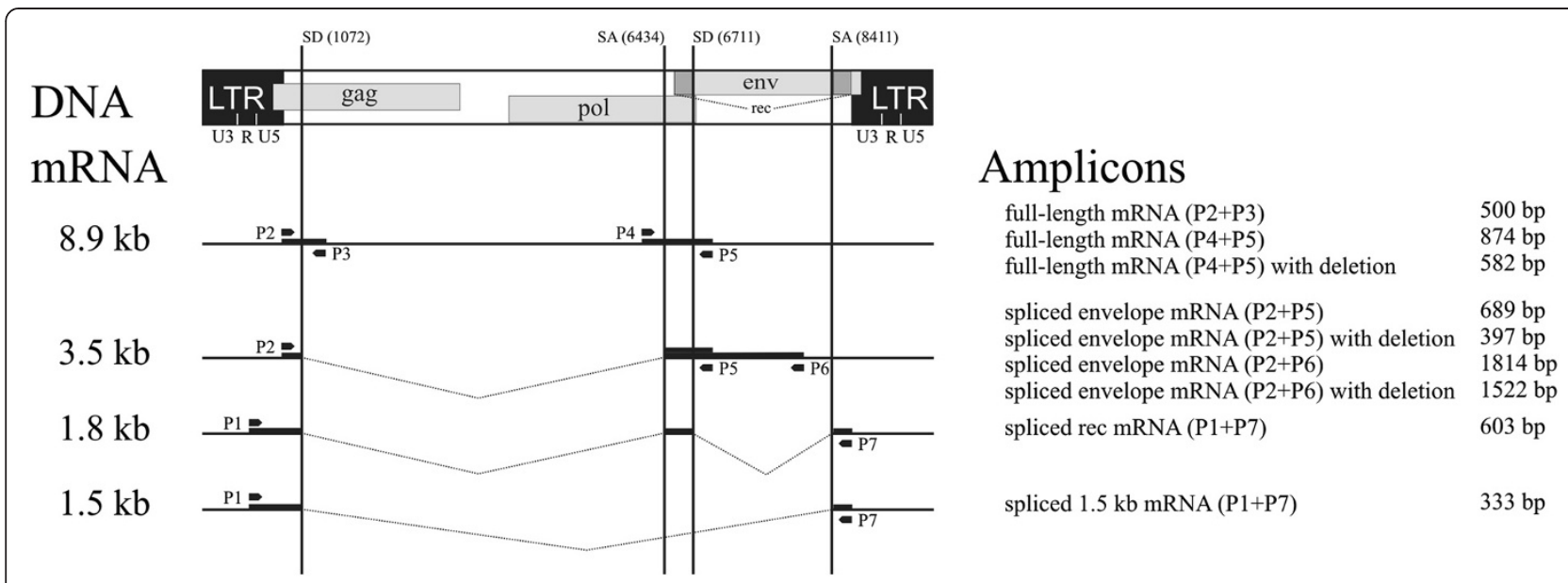

Figure 1 Organization of HERV-K proviruses, expression pattern and primer localization. The localization of the primer pairs (P1 to P7), the splice acceptor (SA) and the splice donor (SD), the size of the mRNA in kilo base pairs (kb) and of the corresponding amplicons in base pairs (bp) are indicated. Modified from [10].

shown that expression of Rec supports cell transformation and induces tumor formation in nude mice [13-15]. Another splice product of the env gene is a $1.5 \mathrm{~kb}$ transcript with unknown function. Alongside the HERV-K prototype structure, a second type of HERV-K proviruses exists. This type is characterized by a fusion of the pol and the env genes due to a $292 \mathrm{bp}$ deletion and the loss of the rec gene [9]. In addition, an open reading frame for the protein Np9 exists. Like Rec, this protein is found in the nucleus, and discussed to have oncogenic potential [15-17].

Transcripts of HERVs have been detected in a multitude of human cancers, but not in the corresponding normal tissue. These findings have been reviewed comprehensively $[2,18]$ : breast cancer, ovarian cancer, lymphoma, melanoma, germ line tumors, haematological neoplasms, sarcoma, bladder cancer, prostate cancer, primary skin tumors and lymphatic metastasis are examples for putative associations between HERV protein expression and cancer development $[2,18]$. Moreover, in blood sera of patients suffering from melanoma and ovarian cancers even antibodies directed against HERV-K gag and env transcripts are detectable [10,19-21]. It has been discussed that these antigens on the surface of cancer cells may be potential targets for a cancer immune therapy [2,22,23]. Indeed, antibodies directed against the HERV-K envelope antigen blocked proliferation of breast cancer cells in vitro and inhibited tumor growth in mouse xenograft models [24].

Patients with glioblastoma multiforme (GBM), the most common malignant brain tumor in adults [25], have a very limited prognosis due to the aggressive local and infiltrative growth pattern of the tumor [26,27]. Standard therapy comprises neurosurgical tumor resection followed by irradiation and concomitant temozolomide (TMZ) chemotherapy and adjuvant TMZ-treatment. Although the overall outcome of GBM patients has improved with the introduction of TMZ, the median survival time still does not exceed 14.6 months after first diagnosis [28]. To overcome the limitations of current treatment regimen, new therapeutic targets have to be defined for tumor celldetection and eradication. Immunotherapy directed against tumor specific antigens may be an option and HERV-K splice products could serve as target. Furthermore, HERV$\mathrm{K}$ derived proteins may play a role during the tumorigenic processes. However, to the best of our knowledge, there are no reports addressing the expression and potential function of HERV-K in human malignant gliomas. Therefore, we elucidated whether HERV-K may be expressed and might play a tumorigenic role in these malignancies.

\section{Methods}

Tissue samples, cell lines and cell culture. Expression of HERV-K was analyzed using normal brain and astrocytic tumor specimens. Informed consent of the patient was obtained for the acquisition of tumor material as approved by the ethics committee of the University of Würzburg (medical faculty). The samples used have been discussed in detail in a previous publication [29]. In addition, five human GBM cell lines (U87, U138, U251, U343 and GaMG) were investigated. The teratoma cell line PA1 served as positive control. These cell lines have been purchased from CLS (Cell Lines Service, Eppelheim, Germany). Primary cells were isolated from patients' GBM tissue samples as described previously [30]. All GBM cells were grown as reported [31] in $75 \mathrm{~cm}$ flasks (Corning, New York, USA) at $37^{\circ} \mathrm{C}$ in an atmosphere of $5.0 \% \mathrm{CO}_{2}$ and $100 \%$ humidity. The PA1 cell line was grown in RPMI-1640 medium supplemented with $10 \%$ fetal calf serum and $25 \mu \mathrm{g} / \mathrm{ml}$ gentamycin (both from Invitrogen, Carlsbad, USA). 
RNA extraction, cDNA synthesis and semiquantitative RT-PCR. Trypsinised cells were washed twice with phosphate-buffered saline. Total mRNA was purified from the cell pellet and from $30 \mathrm{mg}$ of tissue samples by the SV Total RNA Isolation System (Promega, Mannheim, Germany) following the manufacturer's instructions. These instructions recommend a DNAse digest to remove contaminating genomic DNA. $100 \mu \mathrm{l}$ DNAse mix $(80 \mu \mathrm{l}$ yellow core buffer, $10 \mu \mathrm{l} 0.09 \mathrm{M} \mathrm{MnCl}_{2}, 10 \mu \mathrm{l}$ DNAse I, all provided in the kit) were added to each column. The digest was performed for $30-60 \mathrm{~min}$ at $37^{\circ} \mathrm{C}$. Then the purification was continued according to the manual. Purified RNA was eluted from the columns with $100 \mu \mathrm{l}$ RNase-free water and samples were stored at $-80^{\circ} \mathrm{C}$. As a test for contamination with genomic DNA, which would interfere with full legth HERV-K mRNA detection, a PCR reaction was performed using an aliquot of the mRNA before reverse transcription and the PCR-conditions described below. In case of positivity the DNAse digest was repeated as described above for $60 \mathrm{~min}$ at $37^{\circ} \mathrm{C}$.

One to $5 \mu \mathrm{g}$ of the total RNA was reverse-transcribed using the RevertAid H Minus First Strand cDNA Synthesis Kit (Fermentas, Ontario, Canada) and the provided oligo(dT)18 primer as described elsewhere [29].

The HERV-K expression level was determined by semiquantitative RT-PCR. The amount of cDNA was normalized to the intensity of the PCR product of the ubiquitously expressed gene glyceraldehyde-3-phosphate dehydrogenase (GAPDH), which was used as internal control [32,33]. The primer sequences for GAPDH detection were sense 5'-GCAGGGGGGAGCCAAAAGGG-3' and antisense 5' -TGCCAGCCCCAGCGTCAAAG-3'. The full-length HERV-K virus and different splice variants were analysed using a set of seven primers corresponding to HERV-K108/-K10, -K.HOM and related HERV-K (Figure 1). Details about primer sequences, location of primer recognition sites within the virus genome and amplified fragment sizes can be found in [10]. Primer combinations $\mathrm{P} 2+\mathrm{P} 3$, as well as $\mathrm{P} 4+\mathrm{P} 5$ confirm the expression of the full length mRNA, while P4 + P5 also distinguish between the prototype and the deletion mutant. Primer combinations $\mathrm{P} 2+\mathrm{P} 5$ and $\mathrm{P} 2+\mathrm{P} 6$ detect the envelope sequence and P1 + P7 amplify the double spliced rec and the $1.5 \mathrm{~kb}$ mRNA. The polymerase chain reaction was performed using 0.625 U Dream Taq polymerase (Fermentas, Ontario, Canada) in each $25 \mu$ reaction, containing $10 \mathrm{x}$ buffer with $25 \mathrm{mM} \mathrm{MgCl} 2$ (Fermentas, Ontario, Canada). For primer combination P1 + P7 $1 \mu$ l formamid (Eurobio, Courtaboef Cedex, France) was added to the reaction. Thermocycle parameters were as follows: $10 \mathrm{~min}$ at $94^{\circ} \mathrm{C}$; 35 cycles (21 for GAPDH) of $30 \mathrm{sec}$ at $94^{\circ} \mathrm{C}, 30 \mathrm{sec}$ at $60^{\circ} \mathrm{C}$ $\left(68^{\circ} \mathrm{C}\right.$ for $\left.\mathrm{GAPDH}\right), 2 \mathrm{~min}(1 \mathrm{~min}$ for $\mathrm{GAPDH})$ at $72^{\circ} \mathrm{C}$; and

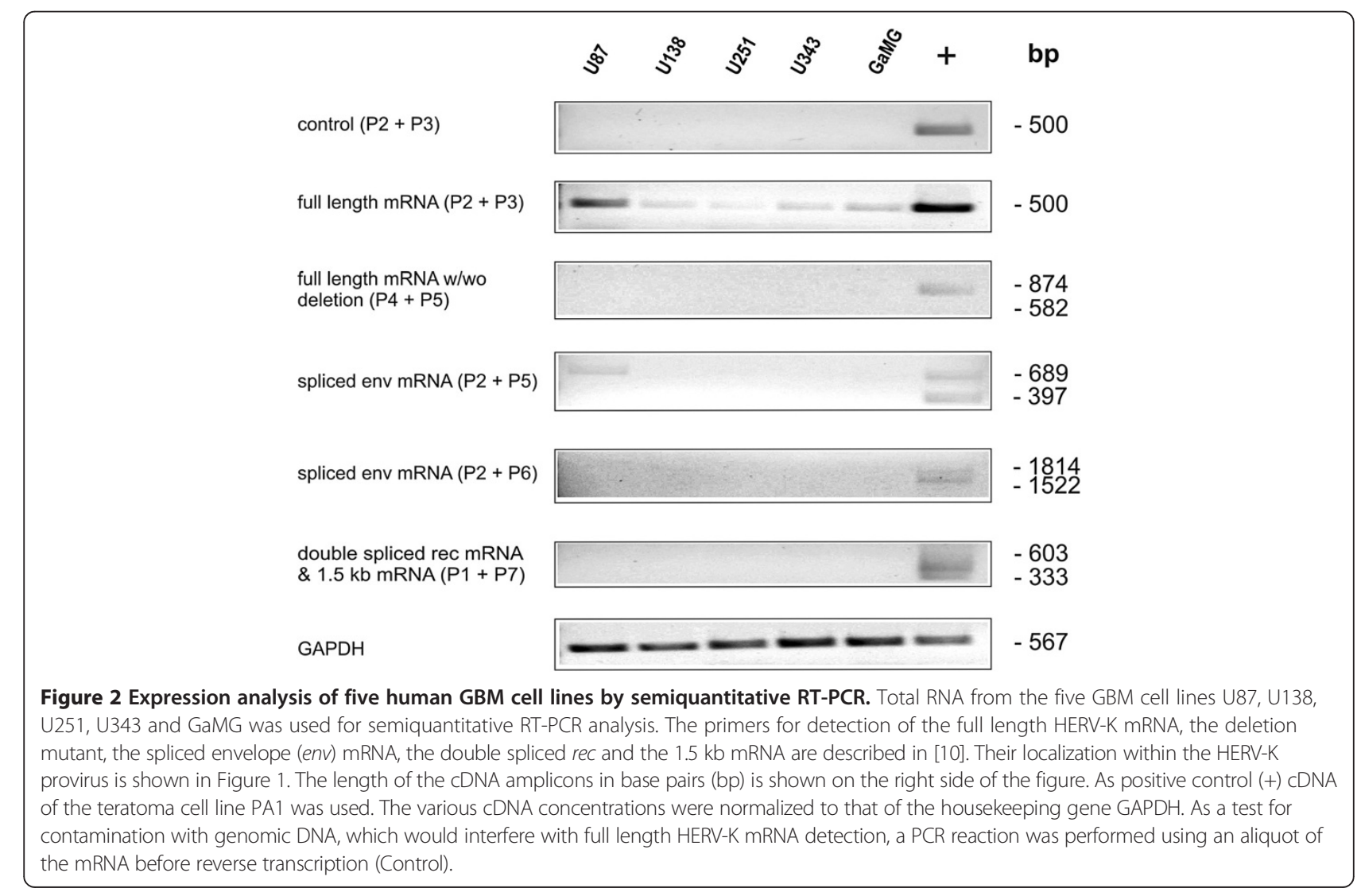




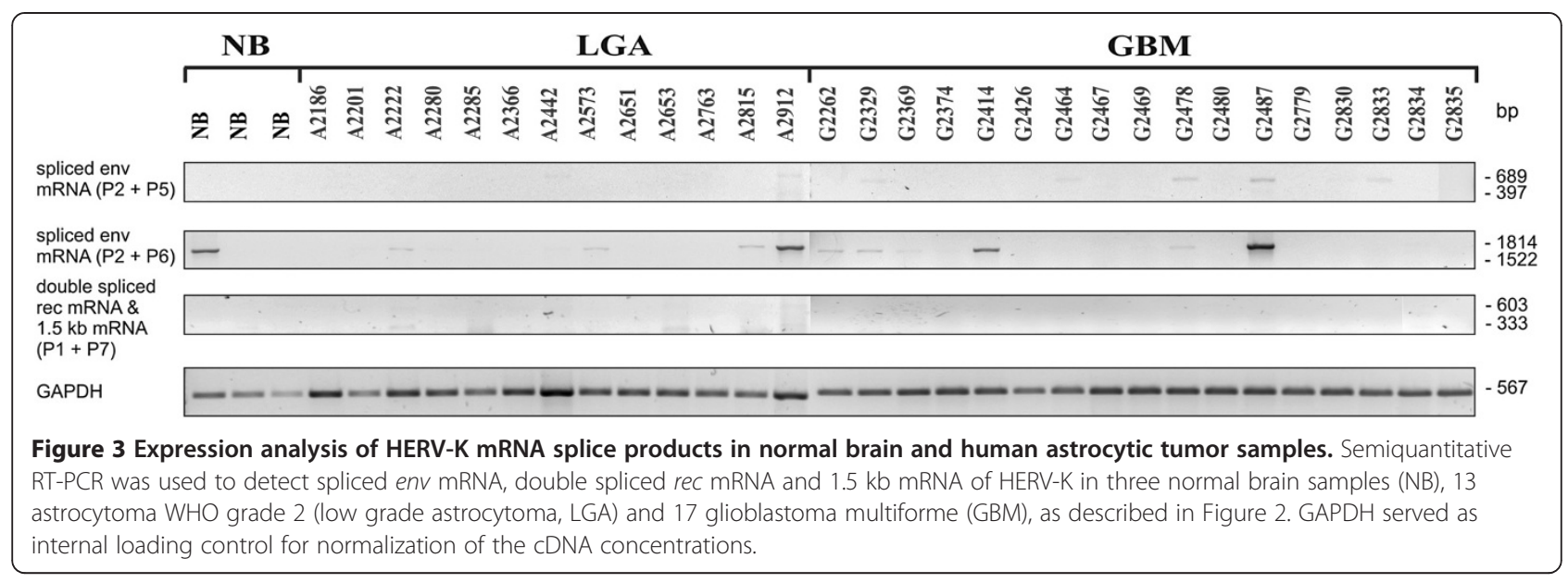

$10 \mathrm{~min}$ at $72^{\circ} \mathrm{C}$. The amplification products were separated on 1\% agarose gels (Sigma-Aldrich, Steinheim, Germany) containing $0.07 \mu \mathrm{g} / \mathrm{ml}$ ethidium bromide (Roth, Karlsruhe, Germany) and photographed using the BioDocAnalyze digital (Biometra, Göttingen, Germany).

\section{Results and conclusion}

Expression of full length HERV-K mRNA and its splice variants env, rec and $1.5 \mathrm{~kb}$ mRNA were analyzed by semiquantitative RT-PCR in different human GBM cell lines, patients' tissue samples of astrocytic tumors and primary cell cultures of different passages. The human GBM cell lines U138, U251, U343 and GaMG displayed weak expression of the full length HERV-K mRNA (Figure 2), while U87 cells showed strong expression. While most of these GBM cell lines have been tested for the first time, the U87 data confirm already published results [10]. The detection of full length mRNA was not due to contamination of the reaction with genomic DNA (Figure 2). However, the deletion mutant could not be detected in these cell lines. U87 cells showed a very weak expression of the 689 bp envelope mRNA. All other splice variants were not detectable in all GBM cell lines tested (Figure 2).
In patients' tissue HERV-K expression was tested in a standardized cDNA panel of three normal brain (NB) tissue samples, 13 astrocytomas WHO grade 2 (low grade astrocytoma, LGA) and 17 GBMs (Figure 3). Due to the limited availability of patients' tissue, only the oncogenically relevant splice variants were checked. In one NB (33\%), one LGA (7.7\%) and two GBM samples (11.8\%) expression of the env mRNA could be detected. However, the splice products $\mathrm{rec}$ and $1.5 \mathrm{~kb}$ mRNA were not found (Figure 3). This suggests that HERV-K splice products do not play a role in human glioma tumorigenic processes and therefore are not suitable as a therapeutic target.

Since passaging of cells in vitro is able to induce mRNA and protein expression of certain proteins [34-36], we analysed a possible induction of HERV-K expression by cellpassaging. Three primary cell cultures were cultured for 6 passages and HERV-K expression was analysed at passage 2 and passage 6 by semiquantitative RT-PCR (Figure 4). Although at passage 2 the $1.5 \mathrm{~kb}$ mRNA was expressed very weakly by all three cultures, there was no expression of any splice product detectable at passage 6 (Figure 4). This may be due to the culture conditions, which seem to

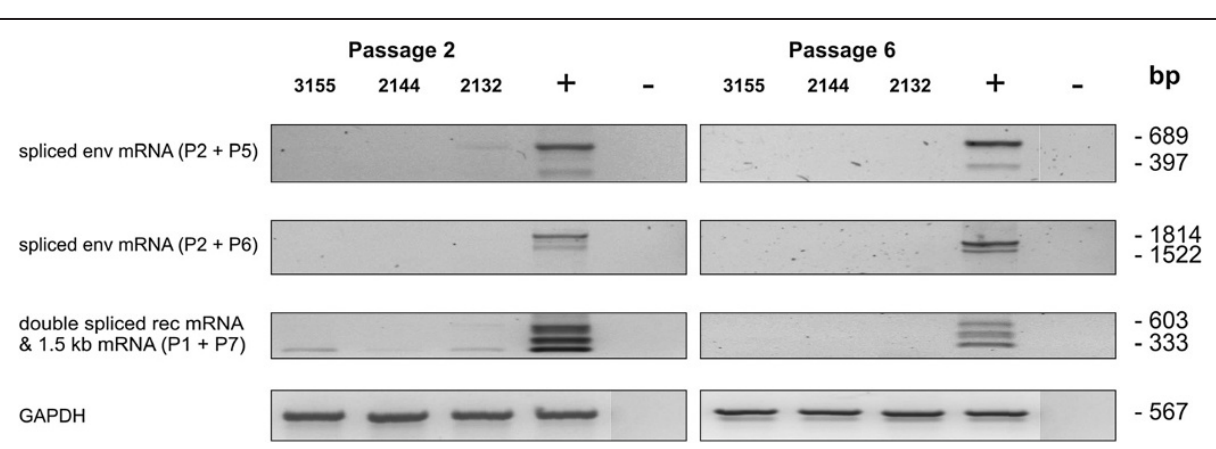

Figure 4 Expression analysis of HERV-K mRNA splice products in primary GBM cells by semiquantitative RT-PCR. Three different primary cell cultures, derived from patients' biopsies, were passaged 6 times. Total RNA was isolated from passage 2 and passage 6 and used for semiquantitative RT-PCR as described in Figure 2. 
adjust the HERV-K expression pattern of primary cells to that seen in established GBM cell lines.

In summary, we found HERV-K full length mRNA expressed in human GBM cell lines. However, the splice variants were neither detectable in GBM cell lines, nor in most of the patients' tissue samples from NB, LGA and GBM. Passaging of primary cells derived from these tumors did not induce HERV-K expression.

Therefore, we conclude that HERV-K, at least the variants which can be detected with the primer pairs we used, is - in contrast to several other cancer types [2] - not expressed in human malignant gliomas, and therefore probably does not play a role in proliferation and progression of these tumors. Our findings do not exclude that other HERVs or other virus types may be involved in modulating the phenotype of GBM cells. For example, it has been shown that sequences and viral gene expression of the human cytomegalovirus (HCMV) can be found in GBM and may act tumor supportive by interaction with key signaling pathways [37].

\section{Abbreviations}

Bp: Base pairs; cDNA: Copy DNA; DNA: Deoxyribonucleic acid;

GAPDH: Glyceraldehyd-3-phosphate dehydrogenase; GBM: Glioblastoma multiforme; HCMV: Human cytomegalovirus; HERV-K: Human endogenous retrovirus K; K: Lysine; kb: Kilo base pairs; LGA: Astrocytoma WHO grade 2; LTR: Long terminal repeat; mRNA: Messenger ribonucleic acid; NB: Normal brain; RT-PCR: Reverse transcription polymerase chain reaction;

TMZ: Temozolomide.

\section{Competing interests}

The authors declare that they have no competing interests.

\section{Authors' contributions}

$\mathrm{CH}, \mathrm{UK}$ and JD participated in the design of the study. AFK, MW and $\mathrm{CH}$ carried out the experimentation procedures and together with JD performed the data analysis and interpretation. $\mathrm{CH}, \mathrm{GHV}$ and $\mathrm{ML}$ coordinated the work. AFK and $\mathrm{CH}$ drafted the manuscript, with help and critical revision by UK, GHV, TL and R-IE. All authors read and approved the final manuscript.

\section{Acknowledgements}

We are very grateful to Stefanie Gerngras and Siglinde Kühnel for technical assistance. We also would like to thank Sven Beyes for his help during an internship in our laboratory.

This publication was funded by the German Research Foundation (DFG) and the University of Würzburg in the funding programme Open Access Publishing.

\section{Author details}

${ }^{1}$ Tumorbiology Laboratory, Department of Neurosurgery, University of Würzburg, Josef-Schneider-Str. 11, Würzburg D-97080, Germany. ${ }^{2}$ Robert Koch Institute, Nordufer 20, Berlin D-13353, Germany. ${ }^{3}$ Department of Obstetrics and Gynaecology, University of Würzburg, Josef-Schneider-Str. 4, Würzburg D-97080, Germany. ${ }^{4}$ Current address: Klinikum Klagenfurt am Wörthersee, Department of Neurosurgery, Feschnigstr. 11, Klagenfurt 9020, Austria.

Received: 31 October 2013 Accepted: 14 March 2014

Published: 19 March 2014

\section{References}

1. Li WH, Gu Z, Wang H, Nekrutenko A: Evolutionary analyses of the human genome. Nature 2001, 409:847-849.

2. Cegolon L, Salata C, Weiderpass E, Vineis P, Palù G, Mastrangelo G: Human endogenous retroviruses and cancer prevention: evidence and prospects. BMC Cancer 2013, 13:4.
3. Löwer R, Löwer J, Kurth R: The viruses in all of us: characteristics and biological significance of human endogenous retrovirus sequences. Proc Natl Acad Sci USA 1996, 93:5177-5184.

4. Tristem M: Identification and characterization of novel human endogenous retrovirus families by phylogenetic screening of the human genome mapping project databese. J Virol 2000, 74:3715-3730.

5. Löwer R, Boller K, Hasenmaier B, Korbmacher C, Muller-Lantzsch N, Löwer J, Kurth R: Identification of human endogenous retroviruses with complex mRNA expression and particle formation. Proc Natl Acad Sci USA 1993, 90:4480-4484.

6. Boeke JD, Stoye JP: Retrotransposons, endogenous retroviruses, and the evolution of retroelements. In Retroviruses. Edited by Coffin JM, Hughes SH, Varmus HE. Cold Spring harbour (NY: Cold Spring Harbour Laboratory Press; 1997.

7. Muster T, Waltenberger A, Grassauer A, Hirschl S, Caucig P, Romirer I, Fodinger D, Seppele H, Schanab O, Magin-Lachmann C, Lower R, Jansen B, Pehamberger $\mathrm{H}$, Wolff $\mathrm{K}$ : An endogenous retrovirus derived from human melanoma cells. Cancer Res 2003, 63:8735-8741.

8. Bannert N, Kurth R: Retroelements and the human genome: new perspectives on an old relation. Proc Natl Acad Sci USA 2004, 101(Suppl 2):14572-14579.

9. Mayer J: Status of HERV in human cells: expression and coding capacity of human proviruses. Dev Biol (Basel) 2001, 106:439-441. discussion 465-475.

10. Büscher K, Trefzer U, Hofmann M, Sterry W, Kurth R, Denner J: Expression of human endogenous retrovirus $\mathrm{K}$ in melanomas and melanoma cell lines. Cancer Res 2005, 65:4172-4180.

11. Khodosevich K, Lebedev Y, Sverdlov E: Endogenous retroviruses and human evolution. Comp Funct Genomics 2002, 3:494-498.

12. Löwer R, Tonjes RR, Korbmacher C, Kurth R, Löwer J: Identification of a Rev-related protein by analysis of spliced transcripts of the human endogenous retroviruses HTDV/HERV-K. J Virol 1995, 69:141-149.

13. Boese A, Sauter M, Galli U, Best B, Herbst H, Mayer J, Kremmer E, Roemer K, Mueller-Lantzsch N: Human endogenous retrovirus protein cORF supports cell transformation and associates with the promyelocytic leukemia zinc finger protein. Oncogene 2000, 19:4328-4336.

14. Galli UM, Sauter M, Lecher B, Maurer S, Herbst H, Roemer K, MuellerLantzsch N: Human endogenous retrovirus rec interferes with germ cell development in mice and may cause carcinoma in situ, the predecessor lesion of germ cell tumors. Oncogene 2005, 24:3223-3228.

15. Denne M, Sauter M, Armbruester V, Licht JD, Roemer K, Mueller-Lantzsch N: Physical and functional interactions of human endogeneous retrovirus proteins Np9 and rec with the promyelocytic leukemia zink finger protein. J Virol 2007, 85:5607-5616.

16. Armbruester V, Sauter M, Krautkraemer E, Meese E, Kleiman A, Best B, Roemer $K$, Mueller-Lantzsch N: A novel gene from the human endogenous retrovirus K expressed in transformed cells. Clin Cancer Res 1800-1807, 2002:8.

17. Chen T, Meng Z, Gan Y, Wang X, Xu F, Gu Y, Xu X, Tang J, Zhou H, Zhang X, Gan X, Van Ness C, Xu G, Huang L, Zhang X, Fang Y, Wu J, Zheng S, Jin J, Huang W, Xu R: The viral oncogene Np9 acts as a critical molecular switch for co-activating $\beta$-catenin, ERK, Akt and Notch 1 and promoting the growth of human leukemia stem/progenitor cells. Leukemia 2013, 27:1469-1478.

18. Voisset C, Weiss RA, Griffiths DJ: Human RNA "Rumor" viruses: the search for novel human retroviruses in chronic disease. Microbiol Mol Biol Rev 2008, 72:157-196.

19. Wang-Johanning F, Frost AR, Johanning GL, Khazaeli MB, LoBuglio AF, Shaw $D R$, Strong TV: Expression of human endogenous retrovirus k envelope transcripts in human breast cancer. Clin Cancer Res 2001, 7:1553-1560.

20. Humer J, Waltenberger A, Grassauer A, Kurz M, Valencak J, Rapberger R, Hahn S, Löwer R, Wolff K, Bergmann M, Muster T, Mayer B, Pehamberger $\mathrm{H}$ : Identification of a melanoma marker derived from melanoma-associated endogenous retroviruses. Cancer Res 2006, 66:1658-1663.

21. Hahn S, Ugurel S, Hanschmann KM, Strobel H, Tondera C, Schadendorf D, Löwer J, Löwer R: Serological response to human endogenous retrovirus $\mathrm{K}$ in melanoma patients correlates with survival probability. AIDS Res Hum Retroviruses 2008, 24:717-723.

22. Wang-Johanning F, Radvanyi L, Rycaj K, Plummer JB, Yan P, Jagannadha Sastry K, Piyathilake C, Hunt KK, Johanning GL: Human endogenous retrovirus $\mathrm{K}$ triggers an antigen-specific immune response in breast cancer patients. Cancer Res 2008, 68:5869-5877.

23. Kraus B, Fischer K, Büchner SM, Wels WS, Löwer R, Sliva K, Schnierle BS: Vaccination directed against the human endogenous retrovirus- $K$ 
envelope protein inhibits tumor growth in a murine model system. Plos One 2013, 8:e72756.

24. Wang-Johanning F, Rycaj K, Plummer JB, Li M, Yin B, Frerich K, Garza JG, Shen J, Lin K, Yan P, Glynn SA, Dorsey TH, Hunt KK, Ambs S, Johanning GL: Immunotherapeutic potential of anti-human endogenous retrovirus- $k$ envelope protein antibodies in targeting breast tumors. J Natl Cancer Inst 2012, 104:189-210.

25. Reifenberger G, Collins VP: Pathology and molecular genetics of astrocytic gliomas. J Mol Med 2004, 82:656-670.

26. Demuth T, Berens ME: Molecular mechanisms of glioma cell migration and invasion. J Neur-Oncol 2004, 70:217-228.

27. Ohgaki H, Dessen P, Jourde B, Horstmann S, Nishikawa T, Di Patre PL, Burkhard C, Schuler D, Probst-Hensch NM, Maiorka PC, Baeza N, Pisani P, Yonekawa Y, Yasargil MG, Lutolf UM, Kleihues P: Genetic pathways to glioblastoma: a population-based study. Cancer Res 2004, 64:6892-6899.

28. Stupp R, Mason WP, van den Bent MJ, Weller M, Fisher B, Taphoorn MJ, Belanger K, Brandes AA, Marosi C, Bogdahn U, Curschmann J, Janzer RC, Ludwin SK, Gorlia T, Allgeier A, Lacombe D, Cairncross JG, Eisenhauer E, Mirimanoff RO, European Organisation for Research and Treatment of Cancer Brain Tumor and radiotherapy Groups, National Cancer Institute of canada Clinical trials Group: Radiotherapy plus concomitant and adjuvant temozolomide for glioblastoma. N Engl J Med 2005, 352:987-996.

29. Stojic J, Hagemann C, Haas S, Herbold C, Kühnel S, Gerngras S, Roggendorf W, Roosen K, Vince GH: Expression of matrix metalloproteinase MMP-1, MMP-11 and MMP-19 is correlated with the WHO-grading of human malignant gliomas. Neurosci Res 2008, 60:40-49.

30. Wagner S, Czub S, Greif M, Vince GH, Süss N, Kerkau S, Rieckmann P, Roggendorf W, Roosen K, Tonn JC: Microglial/macrophage expression of interleukin 10 in human glioblastomas. Int I Cancer 1999, 82:12-16.

31. Hagemann C, Mayer C, Stojic J, Eicker S, Gerngras S, Kühnel S, Roosen K, Vince GH: High efficiency transfection of glioma cell lines and primary cells for overexpression and RNAi experiments. J Neurosci Methods 2006, 156:194-202.

32. Said HM, Hagemann C, Stojic J, Schoemig B, Vince GH, Flentje M, Roosen K, Vordermark D: GAPDH is not regulated in human glioblastoma under hypoxic conditions. BMC Mol Biol 2007, 8:55.

33. Said HM, Polat B, Hagemann C, Anacker J, Flentje M, Vordermark D: Absence of GAPDH regulation in tumor-cells of different origin under hypoxic conditions in vitro. BMC Res Notes 2009, 2:8

34. Hagemann C, Anacker J, Gerngras S, Kühnel S, Said HM, Patel R, Kämmerer $\mathrm{U}$, Vordermark D, Roosen K, Vince GH: Expression analysis of the autosomal recessive primary microcephaly genes $\mathrm{MCPH} 1$ (microcephalin) and MCPH5 (ASPM, abnormal spindle-like, microcephaly associated) in human malignant gliomas. Oncol Rep 2008, 20:301-308.

35. Hagemann C, Anacker J, Haas S, Riesner D, Schömig B, Ernestus R-I, Vince GH: Comparative expression pattern of matrix-metalloproteinases in human glioblastoma cell-lines and primary cultures. BMC Res Notes 2010, 3:293.

36. Tan Q, Lui PP, Rui YF: Effect of in vitro passaging on the stem cell related properties of tendon-derived stem cells - implications in tissue engineering. Stem Cells Dev 2012, 21:790-800.

37. Dziurzynski K, Chang SM, Heimberger AB, Kalejta RF, McGregor Dallas SR, Smit M, Soroceanu L, Cobbs CS, the HCMV and Glioma Symposium: Consensus on the role of human cytomegalovirus in glioblastoma. Neuro Oncol 2012, 14:246-255.

\section{Submit your next manuscript to BioMed Central and take full advantage of:}

- Convenient online submission

- Thorough peer review

- No space constraints or color figure charges

- Immediate publication on acceptance

- Inclusion in PubMed, CAS, Scopus and Google Scholar

- Research which is freely available for redistribution

Submit your manuscript at www.biomedcentral.com/submit
C Biomed Central 